\title{
Pengaruh Penambahan Stabilizer Carboxyl Metyl Celulosa dan Tepung Agar terhadap Karakteristik Fisiko Kimia Velva Sirsak
}

\author{
Gustiarini Rika Putri ${ }^{1}$, Selfa Dewati Samah ${ }^{2}$ \\ ${ }^{\prime}$ Jurusan Teknik Industri Agro, Politeknik ATI Padang, Jalan Bungo Pasang -Tabing Kota Padang Sumatera Barat 25171 \\ ${ }^{2}$ Jurusan Analisis Kimia, Politeknik ATI Padang, Jalan Bungo Pasang -Tabing Kota Padang Sumatera Barat 2517
}

\section{ARTICLE INFORMATION}

Received: June 10, 2021

Revised: June 23, 2021

Available online: June 30, 2021

\section{KEYWORDS}

Agar Powder, CMC, Physico-Chemical,

Soursop, Velva

\section{CORRESPONDENCE}

Name: Gustiarini Rika Putri

E-mail: gustiarini_rika@poltekatipdg.ac.id

\section{A B $\mathbf{S}$ T $\mathbf{R}$ A $\mathbf{C}$ T}

Fruits are perishable agro materials, so further processing is necessary after the fruit is harvest. Soursop is a fruit dessert with characteristics like ice cream. The purpose of this study was determined the appropriate compotition and agar powder in the manufacture of soursop velva so that a product with physical characteristics such as ice cream. The physical characteristics of soursop velva are total solid, water content, $\mathrm{pH}$, vitamin $\mathrm{C}$, fiber, total acid, melting speed and overrun. The soursop velva research method with six treatments, A $(0,4 \% \mathrm{CMC}$ added), B (0,5\% CMC added), C (0,6\% CMC added), D (0,4\% agar powder added), E ( $0,5 \%$ agar powder added), $\mathrm{F}(0,6 \%$ agar powder added). Observation were made on the physico-chemical characteristics of soursop velva. The result shows that soursop Velva added with $0,6 \%$ agar powder content $24,79 \%$ total

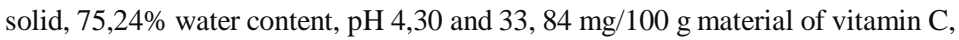
2,2\% fiber, 2,2\% total acid, with 19,69 minutes melting speed and $134,67 \%$ overrun.

\section{PENDAHULUAN}

Buah-buahan merupakan salah satu komoditi agro yang mudah rusak (perishable) sehingga sangat diperlukan pengolahan lanjutan setelah buah tersebut dipanen. Salah satu komoditi agro yang mudah rusak adalah sirsak, dimana buah sirsak matang hanya mampu bertahan 2-3 hari dalam kondisi penyimpanan suhu ruang.

Sirsak (Annona muricata L.) merupakan buah yang memiliki kulit berwarna hijau, berdaging tebal bertekstur lunak dan berwarna putih serta memiliki rasa manis agak asam. Buah sirsak mengandung serat sebanyak 3,3 g yang berfungsi sebagai serat makanan (dietary fiber) untuk memperlancar pencernaan. Sirsak juga mengandung vitamin A sebesar 10,0 SI, vitamin B1 sebesar $0,07 \mathrm{mg}$ dan vitamin $\mathrm{C}$ sebesar $20 \mathrm{mg}$ yang berfungsi sebagai antioksidan yang sangat baik untuk meningkatan imunitas tubuh [1].

Buah sirsak dapat diolah menjadi berbagai produk seperti permen jelly, selai, dodol, dan juga velva. Jika dinilai dari segi harga jual, sirsak termasuk buah dengan harga yang murah dan mudah diperoleh pada pasar tradisional.

Velva buah merupakan salah satu pangan alternatif bagi sebagian orang yang mempunyai masalah kesehatan terhadap produk-produk es krim dengan kandungan lemak tinggi. Menurut [2], velva merupakan campuran dari puree (bubur buah) dengan gula dan bahan penstabil yang dibekukan dalam alat pembeku es krim untuk memperoleh tekstur yang halus. Keunggulan velva dibandingkan dengan makanan beku lain seperti es krim adalah kandungan lemak yang rendah, lebih kaya serat alami dan kandungan vitamin yang tinggi terutama vitamin $\mathrm{C}$ dan provitamin $\mathrm{A}$ ( $\beta$-karoten) yang berasal dari buah sebagai bahan baku. Aroma dan cita rasa yang khas dari buah menjadikan produk velva memiliki daya tarik dan ciri khas yang membedakannya dengan produk sejenis.

Selain dari manfaat yang bisa diberikan oleh velva buah sebagai makanan sehat, velva buah juga harus memiliki sifat fisiko kimia menyerupai es krim. Menurut Arbuckle [3], salah satu parameter penting dalam mengindikasikan 
stabilitas es krim adalah laju pelelehannya. Apabila es krim didiamkan pada suhu ruang, maka kristal es yang terdapat pada es krim dapat meleleh karena adanya transfer panas dari suhu ruang sehingga menyebabkan es mencair. Untuk mempertahankan stabilitas es krim diperlukan adanya zat penstabil. Laju pelelehan atau daya leleh adalah waktu yang dibutuhkan es krim untuk meleleh seluruhnya pada suhu ruang [8].

Penggunaan bahan penstabil dalam formulasi velva buah merupakan faktor penting yang harus diperhatikan untuk menghasilkan velva dengan karakteristik yang lembut hingga menyerupai produk es krim pada umumnya. Hal ini terkait dengan fungsi bahan penstabil, yaitu untuk membentuk tekstur yang lembut, meningkatkan kekentalan, menghasilkan produk yang seragam, mencegah pembentukan kristal es yang kasar, dan memberikan daya tahan yang baik terhadap proses pencairan.

Untuk mendapatkan karakteristik velva yang bisa menyerupai es krim dibutuhkan bahan penstabil dalam pembuatan velva tersebut. Salah satu bahan penstabil yang paling banyak digunakan dalam pengolahan pangan adalah Carboxy Methyl Cellulose (CMC) dan tepung agar.

Kelebihan dari CMC adalah mempunyai kapasitas mengikat air, mudah larut dalam adonan harganya relatif lebih murah. Sedangkan agar banyak digunakan dalam produk olahan pangan karena bersifat meningkatkan viskositas. Umumnya pemilihan jenis bahan penstabil didasarkan terutama atas pengaruhnya terhadap overrun dan tekstur. Selain itu CMC dan tepung agar memiliki harga yang relatif murah di pasaran.

Adapun tujuan dari penelitian ini adalah untuk menentukan konsentrasi CMC dan tepung agar yang tepat dalam pembuatan velva nenas sehingga dihasilkan produk dengan karakteristik fisik seperti es krim.

\section{METODOLOGI}

\section{Bahan dan Alat Penelitian}

Bahan utama yang digunakan dalam penelitian adalah buah sirsak dalam kondisi matang, tekstur buah sudah lunak dan aroma khas buah sirsak. Bahan tambahan yang digunakan adalah CMC, tepung agar, asam sitrat, vitamin $\mathrm{C}$ murni (asam askorbat) dan gula pasir putih serta bahanbahan untuk analisis kimia yaitu $\mathrm{NaOH} 0,1 \mathrm{~N}$, indikator pp, indikator pati, aquades dan larutan iod $0,01 \mathrm{~N}, \mathrm{H}_{2} \mathrm{SO}_{4}$ pekat, $\mathrm{NaOH} 0,313 \mathrm{~N}, \mathrm{~K}_{2} \mathrm{SO}_{4} 10 \%$ dan alkohol $45 \%$.

Alat-alat yang digunakan dalam penelitian meliputi peralatan pembuatan velva sirsak seperti : freezer, mixer, blender, pisau, timbangan, kompor, cup es krim, baskom dan sendok serta alat-alat lain yang digunakan untuk analisis kimia.

\section{Rancangan Penelitian}

Rancangan penelitian menggunakan Rancangan Acak Lengkap (RAL) dengan 6 perlakuan dan 3 ulangan. Hasil pengamatan dari masing-masing parameter dianalisa statistik dengan uji F kemudian dilanjutkan dengan uji Duncan's New Multiple Range Test (DNMRT) pada taraf $5 \%$.

Perlakuan yang digunakan dalam penelitian adalah sebagai berikut :

Perlakuan $\mathrm{A}=$ penambahan $\mathrm{CMC} 0,4 \%$

Perlakuan $\mathrm{B}=$ penambahan CMC $0,5 \%$

Perlakuan $\mathrm{C}=$ penambahan $\mathrm{CMC} 0,6 \%$

Perlakuan D = penambahan agar-agar $0,4 \%$

Perlakuan $\mathrm{E}=$ penambahan agar-agar $0,5 \%$

Perlakuan $\mathrm{F}=$ penambahan agar-agar $0,6 \%$

Selain buah sirsak dan bahan penstabil, bahan lain yang juga digunakan dalam pembuatan velva sirsak adalah air, asam sitrat dan asam askorbat dalam jumlah yang tetap untuk masing-masing perlakuan.

Tabel 1. Formulasi Bahan untuk Masing-masing Perlakuan

\begin{tabular}{lcccccc}
\hline \multirow{1}{*}{ Bahan } & \multicolumn{6}{c}{ Perlakuan } \\
\cline { 2 - 7 } & $\mathbf{A}$ & $\mathbf{B}$ & $\mathbf{C}$ & $\mathbf{D}$ & $\mathbf{E}$ & $\mathbf{F}$ \\
\hline CMC (\%) & 0,4 & 0,5 & 0,6 & 0,0 & 0,0 & 0,0 \\
Tepung Agar (\%) & 0,0 & 0,0 & 0,0 & 0,4 & 0,5 & 0,6 \\
Daging Buah Sirsak (gr) & 250 & 250 & 250 & 250 & 250 & 250 \\
Gula Pasir (gr) & 100 & 100 & 100 & 100 & 100 & 100 \\
Asam Sitrat (\%) & 0,1 & 0,1 & 0,1 & 0,1 & 0,1 & 0,1 \\
Asam Askorbat (\%) & 0,1 & 0,1 & 0,1 & 0,1 & 0,1 & 0,1 \\
Air (mL) & 250 & 250 & 250 & 250 & 250 & 250 \\
\hline
\end{tabular}

\section{Persiapan Bahan}

Proses pembuatan velva sirsak dimulai dengan persiapan bahan baku dengan pembuatan bubur sirsak. Rata-rata berat buah sirsak antara 500-700 g. Untuk 1 sampel dibutuhkan $\pm 250 \mathrm{~g}$ daging buah dan untuk semua sampel dibutuhkan (6 perlakuan dan 3 ulangan) $6 \times 3 \times 250 \mathrm{~g}$ daging buah $=4500 \mathrm{~g}$ daging buah, sehingga banyaknya buah yang dibutuhkan untuk penelitian ini \pm 10 -12 buah sirsak.

\section{Prosedur Kerja}

Pembuatan bubur sirsak mengacu pada [1]. Buah sirsak dipilih yang memiliki ciri-ciri buah seperti kulit hijau merata, jarak durinya tidak terlalu rapat serta tekstur tidak terlalu lunak, lalu dicuci dengan air bersih, selanjutnya buah sirsak dikupas kulit buah dan dibuang bijinya. Daging buah yang diperoleh dihancurkan 
menggunakan blender dengan penambahan air menggunakan perbandingan (1:1) hingga menghasilkan bubur sirsak, dimana banyaknya daging buah sirsak yang digunakan untuk masing-masing perlakuan $250 \mathrm{~g}$. Selanjutnya kedalam bubur buah ditambahkan gula pasir sebanyak $100 \mathrm{~g}$ dan $150 \mathrm{~mL}$ air matang. Campuran kemudian dihaluskan kembali selama \pm 3 menit sampai gula menjadi larut.

Berdasarkan SNI No. 01-3713-1995 tentang syarat mutu es krim dan penelitian pendahuluan terhadap penilaian organoleptik velva sirsak, maka ditetapkan bahan penstabil CMC dan tepung agar sesuai perlakuan $(0,4 \%$, $0,5 \%$ dan $0,6 \%$ dari $250 \mathrm{~g}$ bubur buah) dilarutkan dengan sedikit air dan dipanaskan sampai larut sempurna. Larutan ditambahkan sedikit demi sedikit ke dalam bubur buah sambil terus diaduk sampai merata selama 3 menit. Selanjutnya adalah penambahan asam sitrat dan asam askorbat masing-masing sebanyak $0,1 \%$ dari berat bubur buah yang telah dilarutkan dalam 50\% air, serta sisa air matang dari total air yang digunakan $(50 \%)$. Adonan diaduk selama \pm 3 menit menggunakan mixer pada kecepatan rendah sampai merata. Adonan yang sudah tercampur homogen selanjutnya didinginkan di dalam refrigator bersuhu 5-6 ${ }^{\circ} \mathrm{C} \pm 45$ menit untuk memberi kesempatan kepada bahan penstabil mengikat air bebas yang ada.

Tahap berikutnya adalah pengadukan dengan menggunakan mixer selama 3 menit pada kecepatan rendah. Velva sirsak yang dihasilkan kemudian di kemas menggunakan cup es krim.Tahap terakhir adalah velva yang telah dikemas dikeraskan dalam freezer bersuhu \pm $20^{\circ} \mathrm{C}$ selama \pm 45 menit.

\section{Pengamatan}

Pengamatan dilakukan terhadap velva sirsak berupa analisis karakteristik kimia yang meliputi: kadar air, nilai $\mathrm{pH}$, total padatan, total asam tertitrasi dan kandungan vitamin C. Sedangkan analisis karakteristik fisik seperti overrun dan kecepatan leleh. Overrun merupakan sebuah parameter untuk mengetahui peningkatan volume es krim karena adanya udara yang terperangkap ke dalam adonan es krim akibat proses agitasi [9]. Sebagai pembanding karakteristik fisikokimia velva sirsak, terdapat syarat mutu es krim menurut SNI No. 01-37131995.

Tabel 2. Syarat Mutu Es Krim menurut SNI No. 013713-1995

\begin{tabular}{clll}
\hline No & Kriteria Uji & Satuan & Persyaratan \\
\hline 1 & Sukrosa & $\%$ b/b & Min 8,0 \\
2 & Jumlah Padatan & $\%$ b/b & Min 34 \\
3 & Overrun & Skala industri & $70 \%-80 \%$ \\
& & Skala rumah tangga & $30 \%-50 \%$ \\
\hline
\end{tabular}

\section{HASIL DAN PEMBAHASAN}

\section{Analisis Karakteristik Kimia}

\section{Total Padatan}

Hasil analisis statistik menunjukkan bahwa tingkat pemberian bahan penstabil CMC dan tepung agar tidak berpengaruh nyata terhadap total padatan velva sirsak yang dihasilkan. Pada Tabel 2 disajikan nilai rata-rata total padatan velva sirsak.

Tabel 3. Nilai Rata-rata Total Padatan Velva Sirsak

\begin{tabular}{lc}
\hline Perlakuan & Total Padatan (\%) \\
\hline F (Penambahan Agar 0,6\%) & 24,79 \\
E (Penambahan CMC 0,6\%) & 24,59 \\
C (Penambahan Agar 0,5\%) & 24,13 \\
D (Penambahan Agar 0,4\%) & 24,01 \\
B (Penambahan CMC 0,5\%) & 22,82 \\
A (Penambahan CMC 0,4\%) & 22,66 \\
\hline KK = 6,21\%
\end{tabular}

Pada Tabel 3 terlihat rata-rata total padatan velva sirsak berkisar antara 22,66\% (perlakuan A) sampai 24,79\% (perlakuan F). Walaupun penambahan bahan penstabil tidak berpengaruh nyata terhadap total padatan velva yang dihasilkan, tetapi ada kecendrungan dengan semakin tinggi konsentrasi bahan penstabil maka total padatan velva akan semakin meningkat. Hal ini disebabkan karena CMC dan agar merupakan karbohidrat. Sehingga penambahan bahan penstabil akan meningkatkan total padatan velva.

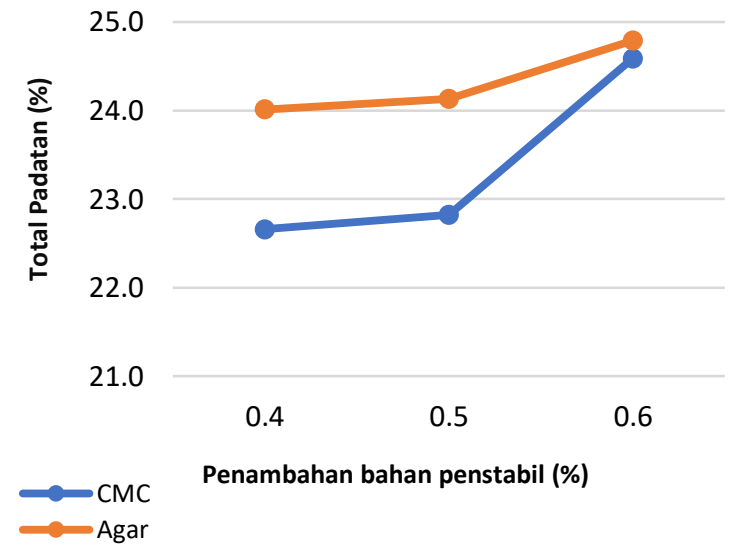

Gambar 1. Grafik Hubungan Antara Jenis dan Konsentrasi Bahan Penstabil Terhadap Total Padatan Velva Sirsak

Padatan velva sirsak yang dihasilkan berasal dari buah sirsak, gula, dan bahan penstabil. Komponen ini memegang peranan penting dalam pembentukan tekstur velva dan memperlambat pelelehan. Total padatan menggantikan jumlah air dalam adonan, menambah nilai gizi dan memperbaiki tekstur velva sirsak yang dihasilkan. Semakin besar total padatan yang ada dalam 
adonan, maka semakin kecil jumlah air yang perlu ditambahkan sehingga dapat mengurangi kristal es yang mungkin terbentuk [3]. Buah sirsak memiliki total padatan yang relatif cukup tinggi sehingga tidak memerlukan penambahan air yang banyak dalam pembuatan velva sirsak.

\section{Kadar Air}

Hasil analisis statistik menunjukkan bahwa tingkat pemberian bahan penstabil CMC dan agar tidak berpengaruh nyata terhadap kadar air velva sirsak. Nilai rata-rata kadar air velva sirsak dapat dilihat pada Tabel 4. Berdasarkan Tabel 4, diketahui bahwa kadar air velva sirsak dengan perlakuan penambahan bahan penstabil mengalami penurunan seiring dengan bertambahnya konsentrasi bahan penstabil, meskipun tidak berbeda nyata. Penurunan ini disebabkan oleh kemampuan dari bahan penstabil untuk mengikat molekul-molekul air melalui ikatan hidrogen yang ada. Dengan semakin tinggi konsentrasi bahan penstabil maka air yang terikat dalam struktur gel yang terbentuk antara bahan penstabil, gula dan asam akan semakin banyak.

Hal ini didukung oleh pendapat Arbuckle [3] bahwa bahan penstabil merupakan koloid hidrofilik yang efektif untuk mengikat air. Kadar air velva sirsak yang dihasilkan berkisar antara 75,24\% (perlakuan F) sampai 77,54\% (perlakuan A).

Tabel 4. Nilai Rata-rata Kadar Air Velva sirsak

\begin{tabular}{lc}
\hline Perlakuan & Kadar Air (\%) \\
\hline A (Penambahan CMC 0,4\%) & 77,54 \\
B (Penambahan CMC 0,5\%) & 76,75 \\
D (penambahan Agar 0,4\%) & 75,77 \\
E (Penambahan Agar 0,5\%) & 75,73 \\
C (Penambahan CMC 0,6\%) & 75,61 \\
F (Penambahan Agar 0,6\%) & 75,24 \\
\hline KK = 2,09\%
\end{tabular}

Pada penambahan agar tenyata nilai rata-rata kadar air velva lebih rendah dibandingkan dengan $\mathrm{CMC}$, hal ini disebabkan oleh banyaknya gugus -OH dan atom oksigen pada struktur agar (Gambar 1), sehingga kesempatan untuk terjadinya ikatan hidrogen antara rantai yang berdekatan akan semakin besar, dengan begitu air yang terikat pada molekul gel pun akan semakin banyak.

Menurut Winarno [4], air merupakan kompanen penting dalam bahan makanan karena dapat mempengaruhi penampakan, tekstur serta cita rasa makanan. Kadar air suatu bahan pangan juga menentukan kesegaran, daya tahan dan penerimaan suatu bahan.

Grafik pengaruh jenis dan konsentrasi bahan penstabil terhadap kadar air velva sirsak dapat dilihat pada Gambar 2 berikut.

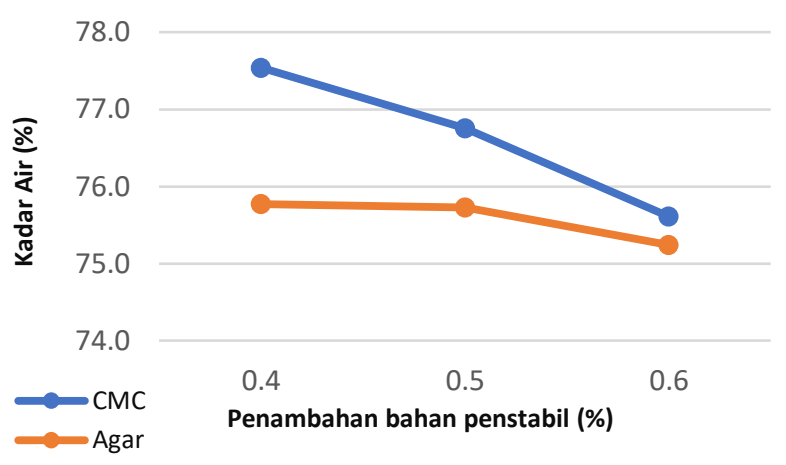

Gambar 2. Grafik Hubungan Antara Jenis dan Konsentrasi Bahan Penstabil Terhadap Kadar Air Velva Sirsak

\section{Kecepatan Leleh}

Hasil analisis statistik menunjukkan bahwa jenis dan konsentrasi bahan penstabil berpengaruh nyata terhadap kecepatan leleh velva sirsak. Nilai rata-rata kecepatan leleh velva sirsak disajikan pada Tabel 5 sebagai berikut.

Tabel 5. Nilai Rata-rata Kecepatan Leleh Velva sirsak

\begin{tabular}{llllll}
\hline Perlakuan & Kecepatan Leleh (menit) \\
\hline F (Penambahan Agar 0,6\%) & 19,69 & a & & \\
C (Penambahan CMC 0,6\%) & 18,45 & a & b & \\
E (Penambahan Agar 0,5\%) & 16,74 & a & b & c \\
D (Penambahan Agar 0,4\%) & 15,48 & & b & c \\
B (Penambahan CMC 0,5\%) & 15,14 & & b & c \\
A (Penambahan CMC 0,4\%) & 13,83 & & & c \\
\hline
\end{tabular}

$\mathrm{KK}=11,51 \%$

Angka-angka pada jalur yang sama diikuti oleh huruf kecil yang sama berbeda tidak nyata pada taraf 5\% menurut DNMRT.

Pada Tabel 5 dapat dilihat bahwa kecepatan leleh velva sirsak berkisar antara 13,83 menit (perlakuan A) sampai 19,69 menit (perlakuan F). Semakin tinggi konsentrasi bahan penstabil maka kecepatan leleh akan semakin lama. Hal ini terjadi karena adanya bahan penstabil dalam adonan akan meningkatkan total padatan, mengikat molekul air bebas sehingga menghambat mobilitas molekul air serta mencegah terbentuknya kristal es selama penyimpanan. Semakin sedikit kristal yang terbentuk pada velva mengakibatkan kecepatan leleh semakin lama. Sesuai dengan pendapat Arbuckle [3], kecepatan leleh velva dipengaruhi oleh total padatan. Peningkatan konsentrasi bahan penstabil dapat meningkatkan total padatan, kekentalan dan mengurangi kadar air dari velva sirsak yang dihasilkan sehingga dapat meningkatkan resistensi pelelehan.

Pada penambahan bahan penstabil agar, ternyata kecepatan lelehnya lebih lama dibandingkan dengan CMC, hal ini dikarenakan jumlah gugus karboksil, dalam molekul agar lebih banyak, sehingga kemampuannya untuk menyerap air sangat besar. Semakin banyak air yang terikat maka kristal es yang 
berbentuk akan semakin sedikit pula, sehingga velva tidak cepat meleleh. Grafik pengaruh jenis dan konsentrasi bahan penstabil terhadap kecepatan leleh velva sirsak dapat dilihat pada Gambar 3.

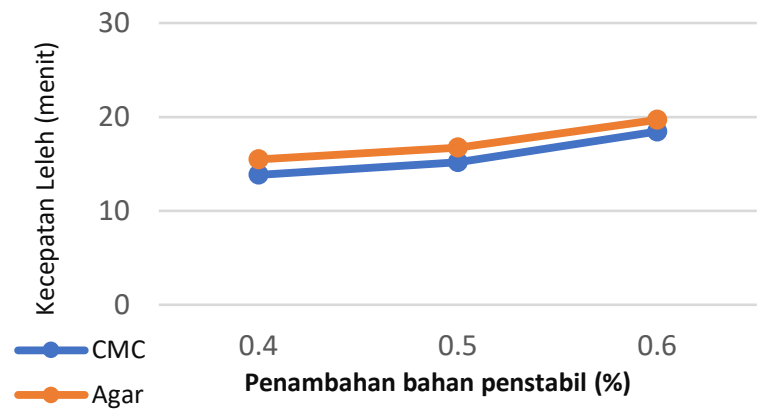

Gambar 3. Grafik Hubungan Antara Jenis dan Konsentrasi Bahan Penstabil Terhadap Kecepatan Leleh Velva sirsak

\section{Nilai pH}

Hasil analisis statistik menunjukkan bahwa perlakuan penambahan bahan penstabil CMC dan agar tidak berpengaruh nyata terhadap $\mathrm{pH}$ velva sirsak yang dihasilkan. Pada Tabel 6 disajikan nilai rata-rata $\mathrm{pH}$ velva sirsak.

Tabel 6. Nilai Rata-rata pH Velva sirsak

\begin{tabular}{ll}
\hline Perlakuan & pH \\
\hline C (Penambahan CMC 0,6\%) & 4,35 \\
B (Penambahan CMC 0,5\%) & 4,32 \\
D (Penambahan Agar 0,4\%) & 4,32 \\
F (Penambahan Agar 0,6\%) & 4,30 \\
E (Penambahan Agar 0,5\%) & 4,21 \\
A (Penambahan CMC 0,4\%) & 4,19 \\
\hline KK = 20,00\% \\
\hline
\end{tabular}

$\mathrm{pH}$ velva sirsak pada penelitian ini berkisar antara 4,19 (perlakuan A) sampai 4,35 (perlakuan C). Nilai $\mathrm{pH}$ velva sirsak yang sama antar masing-masing perlakuan disebabkan karena CMC dan agar sama-sama bersifat netral, sehingga penambahan CMC dan agar dalam adonan tidak mempengaruhi nilai $\mathrm{pH}$ velva yang dihasilkan. Grafik hubungan antara jenis dan konsentrasi bahan penstabil terhadap nilai $\mathrm{pH}$ velva sirsak dapat dilihat pada Gambar 4.

Tingkat keasaman velva mampu membatasi pertumbuhan mikroorganisme, terutama kapang dan khamir. Keasaman pruduk selain disebabkan oleh kandungan asam dari buah sirsak, juga disebabkan oleh penambahan asam sitrat dan asam askorbat. Rasa asam ini diperlukan untuk memberi kesan 'menggigit' (tart taste) pada produk.

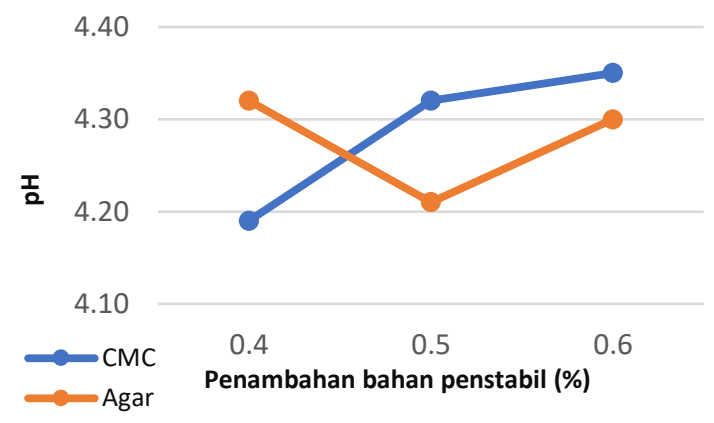

Gambar 4. Grafik Hubungan Antara Jenis dan Konsentrasi Bahan Penstabil Terhadap Nilai pH Velva sirsak

Derajat keasaman suatu bahan atau yang disebut dengan $\mathrm{pH}$ merupakan salah satu faktor penting dalam menentukan ketahanan bahan pangan tersebut terhadap kontaminasi mikroorganisme. Berdasarkan derajat keasamannya, bahan pangan dapat digolongkan ke dalam tiga golongan besar, yaitu (1) bahan pangan berasam rendah dengan kisaran nilai pH 5,3 sampai 4,5; (2) bahan pangan berasam sedang dengan kisaran nilai $\mathrm{pH}$ 4,5 sampai 3,7: (3) bahan pangan berasam tinggi dengan nilai $\mathrm{pH}$ dibawah 3,7 [5]. Jika dilihat dari nilai $\mathrm{pH}$-nya, velva sirsak termasuk kedalam produk pangan berasam sedang karena nilai pH-nya masih diatas 3,7.

\section{Total Asam Tertitrasi}

Hasil analisis sidik ragam menunjukkan bahwa tingkat pemberian bahan penstabil CMC dan agar tidak berpengaruh nyata terhadap total asam velva sirsak. Hal ini dapat terjadi karena adanya penambahan asam sitrat dan asam askorbat dengan konsentrasi yang sama besar $0,1 \%$, sehingga tidak berpengaruh terhadap nilai total asam produk. Nilai rata-rata total asam velva dapat dilihat pada Tabel 7

Tabel 7. Nilai Rata-rata Total Asam Velva sirsak

\begin{tabular}{lc}
\hline Perlakuan & Total Asam (\%) \\
\hline E (Penambahan Agar 0,5\%) & 1,85 \\
F (Penambahan Agar 0,6\%) & 1,79 \\
B (Penambahan CMC 0,5\%) & 1,78 \\
A (Penambahan CMC 0,4\%) & 1,78 \\
C (Penambahan CMC 0,6\%) & 1,72 \\
D (Penambahan Agar 0,4\%) & 1,66 \\
\hline
\end{tabular}

Pada Tabel 7 dapat dilihat bahwa total asam velva sirsak yang dihasilkan berkisar antara 1,66\% (perlakuan D) sampai $1,85 \%$ (perlakuan E). Nilai total asam velva yang hampir sama antar masing-masing perlakuan disebabkan karena CMC dan agar sama-sama bersifat netral, sehingga penambahan CMC dan agar tidak mempengaruhi total asam velva sirsak. Grafik hubungan antara jenis dan konsentrasi bahan penstabil terhadap total asam velva dapat dilihat pada Gambar 5. 


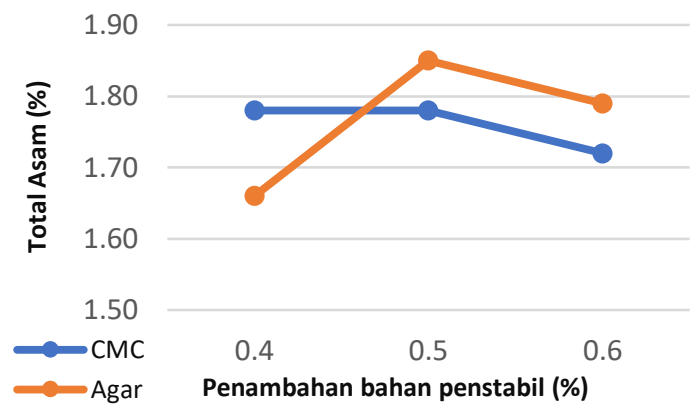

Gambar 5. Grafik Hubungan Antara Jenis dan Konsentrasi Bahan Penstabil Terhadap Total Asam Velva sirsak

\section{Overrun}

Hasil analisis sidik ragam menunjukkan bahwa perlakuan penambahan bahan penstabil berpengaruh nyata terhadap overrun velva sirsak. Nilai rata-rata overrun velva sirsak disajikan pada Tabel 8.

Pada Tabel 8 terlihat bahwa perlakuan B, C, E dan F tidak berpengaruh nyata tetapi berpengaruh nyata terhadap perlakuan A dan D. Nilai overrun velva sirsak yang dihasilkan berkisar antara 22,67\% (perlakuan A) sampai 38,61\% (perlakuan C). Nilai overrun velva sirsak cendrung meningkat seiring dengan meningkatnya kosentrasi bahan penstabil sampai taraf maksimal 0,6\%. Hal ini disebabkan karena bahan penstabil dengan asam dan gula akan membentuk gel yang rapat. Gel yang terbentuk akan meningkatkan viskositas adonan. Bertambahnya viskositas adonan sampai pada taraf maksimal $0,6 \%$ akan mampu menahan gelembung -gelembung udara yang masuk kedalam adonan.

Tabel 8. Nilai rata-rata Overrun Velva sirsak

\begin{tabular}{lc}
\hline Perlakuan & Overrun $\mathbf{( \% )}$ \\
\hline C (Penambahan CMC 0,6\%) & 38,61 \\
F (Penambahan Agar 0,6\%) & 34,67 \\
B (Penambahan CMC 0,5\%) & 34,44 \\
E (Penambahan Agar 0,5\%) & 31,33 \\
D (Penambahan Agar 0,4\%) & 25,69 \\
A (Penambahan CMC 0,4\%) & 22,67 \\
\hline KK = 3,32\% \\
\hline
\end{tabular}

Pengembangan volume velva terjadi selama proses pengocokan. Proses pengocokan mengakibatkan komponen-komponen bahan penstabil menyebar dan membentuk jaringan di sekitar udara dan mengikat air. Menurut Arbuckle [3], pengocokan dilakukan pada suhu rendah (dibawah $10^{\circ} \mathrm{C}$ ) agar terjadi kristalisasi. Proses kristalisasi sangat penting untuk membentuk struktur tiga dimensi yang dapat memerangkap air dan udara sehingga mengakibatkan pegembangan volume velva.
Overrun merupakan salah satu parameter yang penting dalam pembuatan es krim. Pada industri es krim dan makanan pencuci mulut lain, overrun diharapkan mencapai $100 \%$. Semakin besar nilai overrun yang didapat, semakin tinggi keuntungan yang akan dicapai. Nilai ini dapat dicapai dengan proses pembekuan yang optimal [6]. Grafik pengaruh jenis dan konsentrasi bahan penstabil terhadap overrun velva sirsak dapat dilihat pada Gambar 6.

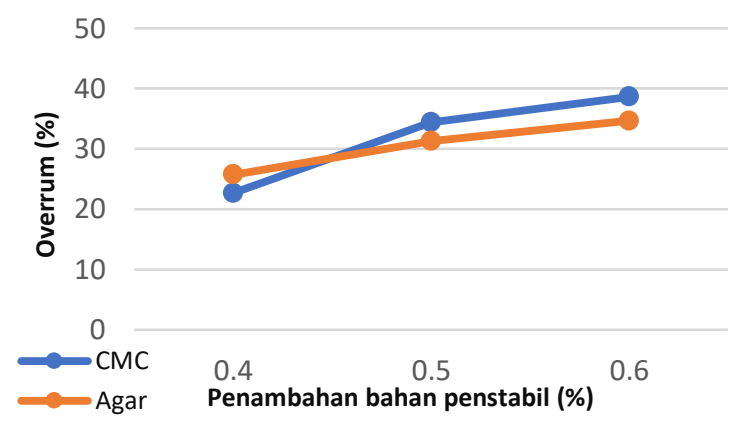

Gambar 6. Grafik Hubungan Antara Jenis dan Konsentrasi Bahan Penstabil Terhadap Overrun Velva Sirsak

\section{Kadar Vitamin C}

Hasil analisis sidik ragam menunjukkan bahwa tingkat pemberian bahan penstabil CMC dan agar tidak berpengaruh nyata terhadap kadar vitamin $\mathrm{C}$ velva sirsak yang dihasilkan. Hal ini disebabkan karena CMC dan agar bukan merupakan sumber vitamin $\mathrm{C}$, sehingga penambahan bahan penstabil tidak mempengaruhi kandungan vitamin $\mathrm{C}$ velva sirsak. Nilai rata-rata vitamin C velva sirsak dapat dilihat pada Tabel 9. Pada Tabel 9 terlihat rata-rata total padatan velva sirsak berkisar antara 22,66\% (perlakuan A) sampai 24,79\% (perlakuan F). Walaupun penambahan bahan penstabil tidak berpengaruh nyata terhadap total padatan velva yang dihasilkan, tetapi ada kecendrungan dengan semakin tinggi konsentrasi bahan penstabil maka total padatan velva akan semakin meningkat. Hal ini disebabkan karena CMC dan agar merupakan karbohidrat. Sehingga penambahan bahan penstabil akan meningkatkan total padatan velva.

Tabel 9. Nilai Rata-rata Vitamin C Velva sirsak

\begin{tabular}{lc}
\hline Perlakuan & $\begin{array}{c}\text { Vitamin C } \\
\text { (mg/100 g bahan) }\end{array}$ \\
\hline A (Penambahan CMC 0,4\%) & 34,45 \\
E (Penambahan Agar 0,5\%) & 34,30 \\
F (Penambahan Agar 0,6\%) & 33,84 \\
D (Penambahan Agar 0,4\%) & 33,70 \\
B (Penambahan CMC 0,5\%) & 33,52 \\
C (Penambahan CMC 0,6\%) & 33,33 \\
\hline KK =6,32\% & 6,32 \\
\hline
\end{tabular}


Pada Tabel 9 dapat dilihat bahwa kadar vitamin C velva sirsak berkisar antara $34,45 \mathrm{mg} / 100 \mathrm{~g}$ bahan (perlakukan A) samapi $33,33 \mathrm{mg} / 100 \mathrm{~g}$ bahan (perlakukan C). Tingginya kadar vitamin $\mathrm{C}$ velva berasal dari buah sirsak yang digunakan dimana kadar vitamin $\mathrm{C}$ nya 35,01 $\mathrm{mg} / 100 \mathrm{~g}$ bahan.

Secara keseluruhan kadar vitamin C untuk masingmaisng perlakuan berpengaruh tidak nyata. Hal ini disebabkan penambahan asam askrobat pada setiap perlakuan sama sebesar $0,1 \%$, sehingga tidak akan mempengaruhi produk secara nyata.

Pada hasil pengamatan $\mathrm{pH}$ terlihat bahwa perlakuan A mempunyai $\mathrm{pH}$ yang lebih rendah dari perlakuan lainnya, dimana dalam keadaan asam ini kandungan vitamin $\mathrm{C}$ pada velva cukup mantap. Sesuai dengan pendapat [4], bahwa vitamin $\mathrm{C}$ akan bertahan dalam suasana asam. Sehingga kehilangan vitamin $\mathrm{C}$ pada perlakukan A relatif lebih sedikit dibandingkan perlakuan lain.

Terjadinya pemantapan vitamin $\mathrm{C}$ akibat dari pemberian bahan penstabil adalah disebabkan karena velva berisi gula, asam dan dengan bahan penstabil akan membentuk gel. Pembentukan gel berarti mengikat vitamin $\mathrm{C}$ yang ada pada buah sirsak. Selain itu sifat hidrofilik dari bahan penstabil menyebabkan bahan penstabil mengikat air melalui ikatan hidrogen dan membentuk sistem koloid [7]. Vitamin C akan terikat secara fisik dalam sistim koloid ini akan melindungi vitamin $\mathrm{C}$, sehingga kehilangan vitamin $\mathrm{C}$ selama pengolahan relatif lebih sedikit, disamping itu adanya penggunaan suhu rendah dalam pembuatan velva sirsak juga akan mempertahankan kandungan vitamin $\mathrm{C}$ pada produk. Grafik pengaruh penambahan bahan penstabil terhadap kadar vitamin C velva sirsak dapat dilihat pada Gambar 7.

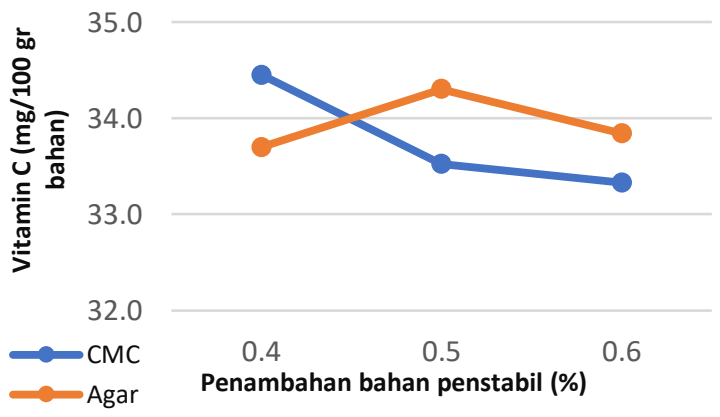

Gambar 7. Grafik Hubungan Antara Jenis dan Konsentrasi Bahan Penstabil Terhadap Kadar Vitamin C Velva Sirsak

\section{KESIMPULAN}

Berdasarkan penelitian yang telah dilakukan, dapat diambil kesimpulan sebagai berikut :
Perlakuan penambahan bahan penstabil CMC dan tepung agar berpengaruh nyata terhadap overrun, kecepatan leleh dan tekstur velva sirsak, tetapi tidak berpengaruh nyata terhadap total padatan, kadar air, nilai $\mathrm{pH}$, total asam, kadar vitamin $\mathrm{C}$, rasa, warna dan aroma velva sirsak.

Perlakuan terbaik ditentukan berdasarkan hasil analisis kecepatan leleh adalah perlakuan dengan penambahan 0,6\% agar (perlakuan F) dengan total padatan 24,79\%, kadar air 75,24 \%, kecepatan leleh 19,69 menit, nilai pH 4,30 , overrun 134,67 \%, vitamin C $33,84 \mathrm{mg} / 100 \mathrm{~g}$ bahan, serat kasar 2,20 \% dan total asam 1,79\%.

\section{DAFTAR PUSTAKA}

[1] Rara. A, V. S. Johan, Y. Zalfiatri. "Pemanfaatan Sirsak dan Nenas dalam Pembuatan Velva". J. SAGU. Vol. 18 No. 2, pp. 1-10, 2019.

[2] Sri. Winarti. Minuman Kesehatan. Surabaya: Trubus Agrisarana. 2006

[3] W.S. Arbuckle and R. T. Marshall. Ice Cream. New York: Chapman and Hall. 2000.

[4] F. G. Winarno. Kimia Pangan dan Gizi. Jakarta: PT. Gramedia Pustaka Utama. 2008.

[5] K. A., Buckle, R. A. Edwards, G. H. Fleet, and M. Wooton. Ilmu Pangan. Penerjemah; Purnomo, Hari dan Adiono. Jakarta: UI. Press. Terjemahan dari : Food science. 365 hal. 2013

[6] D. Goff. Finding Science Ice Cream (Ice Cream Ingridient, Manufacture, Formulation, Structure, and Overrun Calculation). http//www. Foodsci. Uo guelp. Ca/dairy edu/Ice Cream. html[2006]. 2006.

[7] S. Sudarmadji, H. Bambang dan Suharmi. Analisa Bahan Makanan dan Pertanian. Yogyakarta: Liberty. 2010.

[8] Sanggur, Yohana Figerti. 2017. “Kualitas Organoleptik dan Daya lele EsKrim Dengan Penambahan Persentase Buah Nenas Berbeda". Skripsi. Fakultas Peternakan, Universitas Hasanuddin. Makassar

[9] Oksilia., Syafutri, M. I., \& Lidiasari, E. "Karakteristik Es Krim Hasil Modifikasi dengan Formulasi Bubur Timun Suri (Cucumis melo L.) dan Sari Kedelai”. J. Teknologi dan Industri Pangan, Vol. 23, Juni 2012, pp 17-22. 